\title{
ASFIXIA MECÂNICA VERSUS CENTRALIDADE DO TRABALHO: A PANDEMIA QUE DESMASCARA A RETÓRICA CAPITALISTA
}

\author{
Recebido em 12/04/2021, aprovado em 11/06/2021 \\ 10.30612/mvt.v8i14.14462 \\ Marlene Souza dos Santos ${ }^{1}$ \\ Igor Souza de Abreu²
}

\begin{abstract}
RESUMO: Os debates provocados pelo cenário pandêmico que se instaurou no Brasil e no mundo têm demonstrado muitos dos conflitos de interesses sobrepostos entre a dualidade saúde pública versus economia. A nível mundial, diferentes estratégias foram sendo adotadas por governos de modo a conter a letalidade do vírus e concomitantemente manter as atividades econômicas ativas. No Brasil, ao contrário de outras naçôes que privilegiaram desde o início as orientaçóes da Organização Mundial de Saúde (OMS) quanto ao isolamento e distanciamento social, privilegiou-se o funcionamento da economia, o que acarretou o agravamento da crise sanitária no país, que até a presente data já possui taxa de letalidade superior a 486.000 mil mortos. A cartilha pelo qual tem se orientado o governo Bolsonaro trouxe consequências apenas para área da saúde e também o agravamento das já precárias condiçôes de vida e trabalho da classe trabalhadora brasileira. Tendo como norte que o trabalho desempenha papel central na vida dos trabalhadores e na manutenção do capital, objetiva-se no presente artigo discutir como a pandemia do coronavírus tem enfraquecido ainda mais as condiçóes de trabalho dos profissionais do país ao passo que a precarização sucedida tem sido vantajosa para a máxima capitalista de expropriação de valor do trabalho.
\end{abstract}

Palavras-chave: Capitalismo. Pandemia. Expropriação. Trabalho.

\section{MECHANICAL ASPHYXIA VERSUS LABOR CENTRALITY: THE PANDEMIC THAT UNMASKS CAPITALIST RHETORIC}

ABSTRACT: The debates provoked by the pandemic scenario that took place in Brazil and the world have showed many of the overlapping conflicts of interest between the duality between public health and the economy. Worldwide, different strategies have been adopted by governments to contain the lethality of the virus and keep economic activities active. In Brazil, unlike other nations

\footnotetext{
1 Mestranda do Programa de Pós Graduaçáo em Sociologia Política da Universidade Estadual do Norte Fluminense Darcy Ribeiro (UENF). Bacharel em Serviço Social pela Universidade Federal Fluminense, polo universitário de Campos dos Goytacazes (UFF/PUCG). Pesquisadora do Grupo de Pesquisa de Estudos Urbanos e Regionais (Gepur/UENF). Pesquisadora do Grupo de Assessoria ao Trabalho do Assistente Social (GATAS /UFF). E-mail:nenasouza05@gmail.com

2 Mestrando no Programa de Pós Graduaçáo em Sociologia Política pela Universidade Estadual do Norte Fluminense Darcy Ribeiro. Bacharel em Ciências Sociais pela mesma instituição. E-mail: igorsouzadeabreu@gmail.com
} 
and despite the guidelines of the World Health Organization (WHO) regarding isolation and social distance, the economy has been the privileged arena of the government, which has worsened the health crisis in the country, leading to a lethality rate 486.000 thousand deaths by the time of this article was finished. The Bolsonaro government led to consequences for the health area and the worsening of precarious living and working conditions of the Brazilian working class. Bearing in mind that work plays a central role in the lives of workers and in the maintenance of capital, the objective of this article is to discuss how the coronavirus pandemic has weakened the working conditions of the country's professionals, while the precariousness has been advantageous for the capitalist system in expropriating the value of work.

Keywords: Capitalism. Pandemic. Expropriation. Work.

\section{ASFIXIA MECÁNICA VERSUS CENTRALIDAD DEL TRABAJO: LA PANDEMIA QUE DEVELA LA RETÓRICA CAPITALISTA}

RESUMEN: Los debates provocados por el escenario pandémico que se dio en Brasil y en el mundo mostraron muchos de los conflictos de interés que se trasladan a la dualidad entre salud pública y economía. Los gobiernos de todo el mundo han adoptado diferentes estrategias para frenar la letalidad del virus y, al mismo tiempo, mantener en marcha las actividades económicas. En Brasil, a diferencia de otras naciones, sehan privilegiado, desde el principio, politicas distintas de las recomendaciones de la Organización Mundial de la Salud (OMS) en cuanto al aislamiento y la distancia social. La economía ha sido privilegiada, lo que ha agravado la crisis de salud en el país, que hasta el día de hoy, tiene una tasa de mortalidad de más de 486.000 muertes. El folleto que guió al gobierno de Bolsonaro tuvo consecuencias no solo para el área de la salud, sino también para el empeoramiento de las ya precarias condiciones de vida y trabajo de la clase trabajadora brasileña. Teniendo en cuenta que el trabajo juega un papel central en la vida de los trabajadores y en el mantenimiento del capital, el objetivo de este artículo es discutir cómo la pandemia de coronavirus ha debilitado aún más las condiciones laborales de los profesionales en el país, mientras que la precariedad procesada se manifestó a Ser ventajoso para el sistema capitalista en la expropiación del valor del trabajo.

Palabras Clave: Capitalismo. Pandemia. Expropiación. Trabajo.

\section{INTRODUÇÃO}

A pandemia do Coronavírus trouxe à tona várias discussôes em torno da crise econômica gerada pela contaminação e das alternativas para o combate à disseminação do vírus. Nesses debates, um dos temas centrais passou a ser o trabalho, junto com a volta das atividades econômicas do Brasil e reabertura total do comércio. Mais de um ano após a notificação do primeiro caso o Brasil soma até o momento de fechamento deste artigo (junho de 2021), mais de 486.000 vidas perdidas pela doença e os números aumentam vertiginosamente a cada dia.

A imprensa mundial noticia diariamente o caos que se instaurou no sistema de saúde brasileiro e todos os olhos têm se voltado para a não gestão da crise por parte do governo Bolsonaro. Diante do colapso total previsto e exaustivamente alertado por cientistas de todo o país, o que se percebe 
claramente é a defesa da doutrina neoliberal por parte do atual governo Bolsonaro/Guedes e a nítida afinidade entre os discursos e falas do presidente e seu ministro e as orientaçôes do Instituto Mises.

Think-tanks ultraliberais têm atacado o lockdown, associando a medida a uma espécie de ideologia totalitária, política e fanática. Tucker (2021), ao analisar o lockdown como ideologia faz uma analogia ao comunismo, socialismo, fascismo e racismo como "estórias" criadas para chamar a atenção da sociedade e recomenda que se recorra à "história" para que tais teorias sejam refutadas. Ao discutir as regras de distanciamento social,o autor defende o combate ao que denomina lockdownismo, que a seu ver está associado a ideia do puritanismo, ferindo e cerceando liberdades e direitos individuais,colocando-se como uma espécie de cárcere domiciliar, impedindo que as pessoas saiam de casa, sobretudo impedindo-as do necessário lazer.O autor conclama a sociedade a combater os lockdowns, reitera a importância da economia e da manutenção da propriedade privada, desconsidera e coloca em xeque a ciência e os estudos que comprovam a eficácia do distanciamento e isolamento social para a diminuição do contágio. Em meio a um discurso travestido de modernidade, com a defesa da reabertura do comércio e do incentivo ao consumo, a direita ultraliberal tem promovido o total aviltamento da classe trabalhadora, levando-a ao adoecimento e à morte.

Várias pesquisas vêm tomando corpo no intuito de explicar os rebatimentos da pandemia na economia mundial. No entanto, Santos (2020, s.p.) argumenta que " $a$ atual pandemia não é uma situação de crise claramente contraposta a uma situação de normalidade”, uma vez que o avanço do neoliberalismo como atual face do capitalismo vem se rendendo à financeirização da economia e à mundialização do capital e, e em decorrência desse quadro, o mundo tem sido atravessado por um contexto de crise permanente. O que temos acompanhado é o significativo aumento da pobreza, potencializando desigualdades que são o resultado de uma economia disfuncional.

A financeirização da economia, segundo Iamamoto (2007) encobre as formas de exploração da mais valia e o caminho que percorre o capitalismo mundial reforça e aprofunda o processo de desvalorização da força de trabalho. Antunes e Druck (2015) destacam que a substituição do trabalho contratado e regulamentado pelos mais diversos modos de terceirização, informalidade e precariedade, e a consequente ampliaçáo dos mecanismos de extração do sobretrabalho tem na atualidade deixado de se tornar exceçâo para torna-se regra dentro da dinâmica do capitalismo flexível que se instaurou no país e no mundo.

O desmantelamento dos direitos sociais manifestos por meio da informalidade e precarizaçáo dos vínculos trabalhistas não tem sido uma novidade para os estudiosos do mundo do trabalho, entretanto as situaçóes provocadas pela pandemia do coronavírus, somados à grave crise política, econômica e social que se instaurou no país, têm promovido importantes perspectivas de se perceber como o gerenciamento ruim da crise (em especial do sistema de saúde) pelo atual governo tem possibilitado em grande escala a morte daqueles que constituem a principal força de trabalho do país: a morte da classe trabalhadora, evidenciando o caráter original e vigente do trabalho de Karl Marx.

Neste sentido, o presente artigo objetiva, tendo como referência o método do materialismo histórico e dialético, resgatar algumas contribuiçôes do autor de $O$ capital, de modo a compreendermos como o trabalho abstrato e alienado pelo capital submete os homens ao mercado e à economia capitalista, transformando-os em objetos. 


\section{A ATUALIDADE DO TRABALHO NO MUNDO CONTEMPORÂNEO}

A principal contribuição para a apreensão da categoria trabalho em sua concepção ontológica é de fundamental importância, tanto para entendermos as especificidades das formas contemporâneas de exploração que vêm moldando otrabalho a partir da sociabilidade capitalista, quanto para demonstrar a atualidade da discussão que propôs Marx.

Trabalho, segundo Marx (2013, p. 255), é "antes de tudo um processo entre ser humano e natureza, processo este em que o homem, por sua própria ação, medeia, regula e controla seu metabolismo com a natureza." Através da sua força vital, o trabalho realizado por seus braços, pernas, cabeça e máos o homem é capaz de modificar a natureza externa e modifica a si mesmo, a sua própria natureza.

O homem, ao se utilizar do seu próprio corpo realiza um trabalho teleológico, uma vez que age de forma consciente, com a finalidade de suprir suas necessidades. Ao comparar o trabalho de uma abelha ao de um arquiteto, Marx (2013) demonstra o quão importante é o trabalho do homem, sendo somente este capaz de idealizar e transformar a natureza. $\mathrm{O}$ autor destaca que "uma abelha envergonha muitos arquitetos com a estrutura de sua colmeia. Porém, o que desde o início distingue o pior arquiteto da melhor abelha é o fato de que o primeiro tem a colmeia em sua mente antes de construí-la com a cera” (MARX, 2013, p. 255).

Marx defende o trabalho como categoria fundante do ser social, a base da sociabilidade humana,

[...] na produção social da própria existência, os homens entram em relaçóes determinadas, necessárias, independentes de sua vontade; essas relaçóes de produçáo correspondem a um grau determinado de desenvolvimento de suas forças produtivas materiais. A totalidade dessas relaçôes de produção constitui a estrutura econômica da sociedade, a base real sobre a qual se eleva uma superestrutura jurídica e política e à qual correspondem formas sociais determinadas de consciência. $\mathrm{O}$ modo de produçâo da vida material condiciona o processo de vida social, política e intelectual. Não é a consciência dos homens que determina o seu ser; ao contrário, é o seu ser social que determina sua consciência” (MARX, 2008, p. 47).

Nossa análise parte da constataçáo de que a centralidade do trabalho vem sendo amplamente atacada e, aliadas a isso, estão as contradiçóes impostas pelo modo de produção capitalista: as novas formas de exploração da força de trabalho, as desregulamentaçôes impostas pelo Estado e mercado ao abolir direitos trabalhistas e o arrefecimento da luta sindical são ingredientes desse modelo.

Os debates em torno da flexibilização das leis trabalhistas, a partir da década de 1990, ganhou fôlego alicerçados, sobretudo, no processo de globalização financeira com aval do governo Collor e, posteriormente, com mais intensidadeno governo Fernando Henrique Cardoso.Com o intuito de sobrepor o "negociado sobre o legislado" as premissas para a flexibilização das relaçôes trabalhistas eram uma forma de combater o desemprego e a "informalidade, pois se fazia necessário ajustar a regulamentação do trabalho às transformaçôes tecnológicas e de competição contemporâneas" (KREIN, 2018, p. 81). A intensa insegurança provocada pela competitividade, a desregulamentação das leis trabalhistas e a fragilização das instituiçóes públicas, a exemplo a Justiça do Trabalho, abrem espaço para a ilegalidade e novas formas de exploração (KREIN, 2018, p. 95). 
Segundo aponta Lessa (2012) o excedente de produçáo (o consumo não acompanha o crescimento do potencial produtivo), o desemprego, as novas formas de atuaçáo do Estado, dentre outros fatores, têm normalizado a crise e as formas do capital se reproduzir, num processo quase ordinário:

[...] é essa permanência de uma "crise" convertida em situação de "normalidade" que fornece as bases empíricas imediatas para as teorizaçōes que afirmam haver uma nova relação entre trabalho e sociabilidade, ou mesmo uma sociabilidade que não carece do trabalho como seu fundamento. A destruição de postos de trabalho, a eliminação de profissōes tradicionais, a "reestruturação produtiva", a hipertrofia do capital financeiro "globalizado", a generalização dos "trabalhadores hifenizados", o desenvolvimento das comunicaçôes e da "economia pontocom" da internet, além de outras tendências contemporâneas, são os argumentos empíricos dos quais se retira legitimidade a favor das teorizaçóes que postulam não ser mais o trabalho a categoria central do mundo dos homens (LESSA, 2012, p. 38-39).

Contrariando o entendimento de que o trabalho tem perdido sua relevância no mundo contemporâneo, Antunes (2014) indica que apesar do capitalismo ter sido afetado por fortes mutaçóes nas últimas décadas, o que tem se revelado de modo factual e pragmático é apenas uma nova morfologia das relaçóes de trabalho. $\mathrm{O}$ autor salienta que, com a reestruturação produtiva desencadeada a partir dos anos de 1970, a classe trabalhadora vem sofrendo uma série de transformaçóes.

A redução do proletariado industrial, fabril, tradicional, manual, estável e especializado para formas mais desregulamentadas de trabalho, os terceirizados, subcontratados, part-time (novo proletariado fabril e de serviços), o aumento significativo do trabalho feminino, a crescente expulsão dos jovens e dos considerados idosos pelo capital (idade próxima aos 40 anos) têm se constituído como a realidade da classe trabalhadora no capitalismo moderno, marcado sobretudo pela informalidade, desemprego estrutural e "trabalhos voluntários" (ANTUNES,2014).

Os mecanismos pelos quais empresas vêm, na atualidade, burlando a legislação social do trabalho, tem contribuído para intensificação do panorama descrito acima aprofundando as contradiçóes do sistema. Além das partiçóes entre trabalhadores estáveis e precários, qualificados e desqualificados, incluídos e excluídos, Antunes (2014, p. 41) indica que "em plena era da informatização do trabalho no mundo maquinal-digital, vem ocorrendo também um processo contraditório, marcado pelo aumento da informalização do trabalho, presente na ampliação dos terceirizados". Assim:

As novas modalidades de exploração intensificada do trabalho, combinadas com um relativo avanço tecnológico em um país dotado de um enorme mercado consumidor tornaram-se elementos centrais da produção capitalista no Brasil. A articulaçáo complexa existente entre financeirizaçáo da economia, neoliberalismo, reestruturação produtiva e as mutações no espaço microcósmico do trabalho e da empresa não poderia deixar de afetar profundamente a classe trabalhadora (ANTUNES,2014, p. 41).

Praun (2020) adverte em base aos dados coletados da Pesquisa Nacional por Amostra de Domicílios (PNAD), o quanto têm crescido os índices de desemprego no país, tendência esta que propende a alastrar-se ainda mais diante do quadro de recessão vislumbrado para a economia mundial. De acordo com a autora, parte desse movimento "já pode ser observado nas quase um milhão 
de solicitaçóes de seguro-desemprego registrados pelo Ministério da Economia somente ao longo de maio de 2020" (PRAUN,2020, p. 2). Para além desta tendência, a pesquisa aponta a acentuação da informalidade e consequente precarização do trabalho já tem atingido $40 \%$ da força de trabalho brasileira, fenômeno este que tende a agravar-se ainda mais com a pandemia de Covid-19.

A crise provocada pelo coronavírus e sua interconexáo com a crise econômica do país, desde logo tem propiciado profundos impactos na classe trabalhadora. Se antes da pandemia o cenário do país indicava, especialmente acerca das novas formas de organização do trabalho associadas aos usos das tecnologias de informação e comunicação (TIC), a cristalização e legitimação da exploração do trabalho, com a pandemia estamos "à beira de um colapso social profundo, sendo o capitalismo, em sua variante ultraliberal, ainda mais corrosivo" (ANTUNES, 2020, p. 115).

De acordo com Praun (2020), a pandemia, assim como as medidas de isolamento e distanciamento social apregoadas pela Organização Mundial da Saúde (OMS), trouxe à tona contradiçóes e desigualdadespré-existentes. O auxílio emergencial, solicitado por mais de 107 milhôes de trabalhadores informais (MÁXIMO, 2020) somado a contaminação e letalidade do vírus sobretudo nas periferias dos grandes centros urbanos demonstrou a deficiência e ineficácia de gestão do país a garantir ao menos a sobrevivência daqueles que configuram em sua grande maioria a classe trabalhadora.

Essa falta de articulação entre os setores governamentais deixa claro o pouco interesse destas em relação a questóes como a realidade de redução da renda, a dificuldade de acesso às políticas de renda mínima, a deficiência da rede de assistência farmacêutica. $\mathrm{O}$ que se percebe é que o poder público desconsidera os determinantes sociais da saúde e as condiçóes de vida da população, transformando-a em números (FIOCRUZ, 2020, p. 40).

O uso de máscaras e o distanciamento social são, segundo cientistas de todo o mundo, a única forma de controle da disseminação do vírus até que toda a população seja vacinada. Segundo dados recentes da Sala de Situação Covid-19 nas Favelas, vinculada ao Observatório Covid-19 da Fundação Oswaldo Cruz (FIOCRUZ), "a maior ocorrência da doença nos adultos pode estar associada a maior circulação e contato social desse grupo que trabalha [...] e por essa razão não estão em distanciamento social" (FIOCRUZ, 2020, p. 33).

A flexibilização das atividades com a abertura precoce de vários setores e a volta ao trabalho não essencial é responsável pela maior circulação do vírus e, por conseguinte, ao aumento de pessoas contaminadas, reforçando o entendimento de que a crise sanitária traz à tona a desigualdade social, uma vez que os trabalhadores são obrigados a retornar à atividade mesmo colocando em risco sua saúde (ABREU; SANTOS,2021). Assim, como aponta Antunes (2021, p. 114), a "letalidade da pandemia do capital se estampa em sua aguda tragicidade em relação ao trabalho: se forem laborar, contaminam-se; se ficarem em isolamento, não terão recursos mínimos para sobreviver".

No Brasil, milhares de trabalhadores perderam o emprego antes e durante a pandemia. Os períodos de recessão, a partir de 2015, apresentados pelo Instututo de Pesquisa Econômica Aplicada (Ipea) (2021), demonstram que o desemprego gerado pela crise não retrocedeu, ao contrário, a pandemia agravou o quadro no país, "que chegou a 70,5\% no terceiro trimestre de 2020, ou seja, mais de dois terços da população desempregada num trimestre não conseguiu uma ocupação no trimestre seguinte e se manteve na condição de desempregada" (IPEA, 2021, p. 9).

Os dados chamam a atenção para as características individuais dos desempregados: mulheres, negros e indígenas são os que mais perderam postos de trabalho. $\mathrm{O}$ relatório revela, ainda, que somente trabalhadores com alta escolaridade têm conseguido manter-se empregados em função da possibilidade do trabalho remoto (IPEA, 2021). Portanto: 
As respostas do grande capital estáo mais do que evidenciadas: um modelo antissocial, fundado na acumulação capitalista e na riqueza privatizada a todo custo, respaldada na ilimitada exploração e espoliação do trabalho, na corrosão completa dos direitos sociais, na destruição da natureza, no racismo, no sexismo, na homofobia, na xenofobia, tudo isso sob o embalo da mais horripilante forma de poder da modernidade, que é a aberração fascista (ANTUNES, 2021, p. 118).

Outro dado relevante é a retração de setores que diminuíram consideravelmente o número de empregados e vêm sendo afetados tanto pela recessáo de 2015, quanto pela pandemia. Segmentos como alojamento, trabalho doméstico, alimentação, educação e comércio foram duramente prejudicados, sendo que o trabalho informal sofreu considerável redução em função das medidas de isolamento e distanciamento social (IPEA, 2021).

A precarização das condiçôes de vida e trabalho, a atribuição de um valor superior ao valor real no âmbito dos serviços e a dependência cada vez maior do trabalhador com relação ao mercado, segundo Mota (2017, p. 10-11) são tendências do capitalismo contemporâneo. A mercantilização e privatização dos bens e serviços considerados públicos obriga o trabalhador a suprir tanto suas necessidades básicas quanto se responsabilizar pela sua reprodução social. Dessa forma, o trabalhador passa a ser o único responsável pela sua sobrevivência, ficando o Estado como gestor das políticas de exceção - políticas de transferências de renda - e transferindo para as Organizaçóes NáoGovernamentais (ONGs), fundaçôes e associações o papel "caridoso" do enfrentamento da pobreza.

Fica patente que a crise econômica acirrou as desigualdades postas, no entanto a pandemia também escancara a precarização das condições de trabalho e de vida da classe trabalhadora. Pensar a classe que vive do trabalho e como ela se organiza requer reconhecer que existe uma divergência entre o direito legal e sua efetivação.

\section{COVID-19 E PRECARIZAÇÃO DO TRABALHO: FACES DE UMA MESMA MOEDA}

A reestruturação produtiva e do trabalho em curso, junto com a incorporação da ciência e da tecnologia aos processos de produção e gestão do capital, reconfigurou e vem transformando o setor de serviços, desde a década de 1970 .

No atual cenário de pandemia, analisamos, a partir do estudo de Antunes (2021), que essa expansão do trabalho em serviços e esferas não diretamente produtivas, mas que estão intencionalmente relacionadas ao trabalho produtivo, têm ganhado força e contribuído substancialmente para compreendermos a noção ampliada de trabalho. Exemplo desta manifestação pode ser expresso sob o olhar das novas formas de trabalhos remotos e homeoffice, que vêm ganhando força nos últimos anos e, sobretudo, na pandemia. Sobre a incorporaçáo da tecnologia como novo modelo de trabalho Praun (2021) destaca o seguinte:

A tecnologia, apresentada como promessa de uma vida com mais tempo livre e com mais horas em casa, para muitos é tida como possibilidade de livrar-se do controle imposto pelas relações de trabalho tradicionais e, enfim, poder ser patrão de si-próprio. Insinua-se como um sopro de novas possibilidades criativas em um mundo do trabalho cada vez mais desumanizado. Mas, na verdade, o que impele milhares de homens e mulheres, sobretudo os mais jovens, a aderir ao trabalho mediado por tecnologias digitais, hiperflexibilizado, muitas vezes disfarçado de 'autônomo', é a imposição da necessidade de sobreviver (PRAUN, 2021, p. 5). 
Diante disso, interessa aqui analisar as diferentes formas a que se adaptam os trabalhadores, inseridos ou não no mercado de trabalho formal, considerando o contexto da pandemia, sobretudo reconhecendo a exploração e precarização do trabalho como armas que sustentam e reproduzem todas artimanhas engendradas pelo capital no intuito de se manter e fortalecer seus meios de apropriação.

As mudanças que o mundo do trabalho vem experimentando ao longo dos últimos anos têm trazido importantes reflexôes no que concerne às garantias dos direitos sociais dos trabalhadores ou, melhor dizendo, a sua não garantia. As contradições presentes no capitalismo contemporâneo têm suscitado, especialmente com o advento da pandemia do coronavírus, uma perspectiva mais ampla para entendermos a quantas andam a suposta seguridade dos trabalhadores nacionais, em particular aqueles com vínculos de trabalho formal.

Os servidores públicos que experimentavam, antes da pandemia - pelo menos dentro do imaginário social - uma maior segurança, proteção e estabilidade, para efetivar suas atividades têm agora sido expostos também, apesar da formalidade dos vínculos empregatícios, à precarização em suas condiçôes, tanto de vida, quanto de trabalho.Profissionais da saúde e professores, por exemplo, têm, no atual cenário, demonstrado que as dificuldades que a classe trabalhadora informal experimenta também são passíveis de serem reproduzidas dentro dos postos de trabalho formalizados, obviamente em graus diferentes, variando de acordo com a atividade laboral desempenhada.

$\mathrm{Na}$ linha de frente no combate à pandemia, os profissionais de saúde representam de forma clara a precariedade nas condiçôes de trabalho. Segundo dados do Conselho Federal de Enfermagem (COFEN, 2021), o Brasil responde por um terço das mortes desses profissionais por Covid-19. A contaminação e morte dos profissionais de enfermagem também foi responsável por aquecer o mercado de vagas na área da saúde, o que representa um risco, uma vez que os novos contratados assumem os postos de trabalho sem experiência e com parco treinamento, colocando em xeque valorização da vida humana, corroborando o que Marx (2013) denominou exército industrial de reserva:excedente e necessário ao desenvolvimento do capital.Além do risco de contaminação existe também a sobrecarga de trabalho, que chega a 80 horas semanais quando por lei não poderiam passar de 40 horas. Trabalhadores da área da saúde alertam para o náo cumprimento das normas técnicas por parte dos gestores, tanto públicos, quanto privados (COFEN, 2021).

Os dados disponibilizados pela recente pesquisa da Fiocruz, Condiçóes de Trabalho dos Profissionais de Saude no Contexto da Covid-19 em todo o território nacional expressam como os direitos destes trabalhadores vêm sendo deixados de lado em nome de uma "solidariedade" aparentemente esperada por parte dos empregadores e da sociedade, uma vez que "os dados revelam [...] que quase $50 \%$ admitiram excesso de trabalho ao longo desta crise mundial de saúde, com jornadas para além das 40 horas semanais," e, destes, $45 \%$ ainda necessitariam de mais de um emprego para sobreviver (COFEN, 2021, s.p.).

Os direitos vão sendo substituídos por uma espécie de obrigação em nome do amor. A mídia tem associado profissionais de saúde à imagem de heróis e tal imagem foi paulatinamente sendo internalizada pela sociedade, porém a realidade revela que os "heróis" da vida real adoecem, morrem, são explorados, extremamente precarizados e, como expôs Marx (2013), tão logo sejam contaminados ou percam suas vidas são prontamente substituídos. Entretanto, todas as categorias profissionais foram afetadas pelas restriçôes impostas devido à pandemia e em grande medida a educação foi amplamente atingida, considerando-se o caráter coletivo das atividades desenvolvidas nas escolas. Os professores das escolas públicas e privadas tiveram obrigatoriamente que se adaptar ao trabalho remoto, em home office, ao uso das novas tecnologias e a dividir as atividades laborais e privadas em um mesmo espaço. 
Essa nova configuração do trabalho traz à tona duas questôes: a primeira diz respeito à responsabilização do profissional pelos custos do trabalho, uma vez que o professor trabalha e se utiliza dos meios pagos por ele próprio. A segunda questão diz respeito ao sentido do trabalho discutido por Antunes (2018, p. 338): "uma vida cheia de sentido fora do trabalho supóe uma vida dotada de sentido dentro do trabalho". A flexibilizaçáo coloca o trabalhador disponível 24 horas por dia, extremamente funcional ao capital, fazendo com que o trabalho dos professores se assemelhe ao que Antunes e Filgueiras (2020) denominam como o processo de uberização do trabalho. De acordo com os autores,

[...] a chamada uberização do trabalho somente pode ser compreendida e utilizada como expressão de modos de ser do trabalho que se expandem nas plataformas digitais, onde as relaçóes de trabalho são cada vez mais individualizadas (sempre que isso for possível) e invisibilizadas, de modo a assumir a aparência de prestação de serviços. Mas, os traços constitutivos de sua concretude, como veremos a seguir, são expressão de formas diferenciadas de assalariamento, comportando tanto obtenção de lucro, exploração do mais valor e também espoliação do trabalho, ao transferir os custos para seus/suas trabalhadores/as que passam a depender diretamente do financiamento de suas despesas, que são imprescindíveis para a realizaçáo de seu labor (ANTUNES; FILGUEIRAS, 2020, p. 32).

Apesar dos autores se basearem nas relações de trabalho informais para representarem essa dinâmica descrita acima, propomos aqui certa apropriação desta discussão para problematizarmos a seguinte questáo: a pandemia tem nos mostrado que novas formas de precarizar o trabalho têm sido engendradas pelo capital de modo a enfraquecer o mínimo de garantias trabalhistas asseguradas (até então) pelos vínculos empregatícios formais. O home office, que vem sendo a estratégia adotada pelo sistema educacional para enfrentar os obstáculos produzidos pelo cenário de pandemia, fortalece o estado de desamparo dos profissionais da educação no país.O "professor delivery", que vem ganhando forma ao longo dessa conjuntura marcada pela pandemia do coronavírus, tem demonstrado de maneira explícita a linha tênue que se encontra entre o trabalho precarizado formal e informal no país. Ao assumir o home office como estratégia, são os professores que têm experimentado os desajustes presentes no mundo do trabalho precarizado.

O aumento de jornada de trabalho e a consequente exploração da mais valia proveniente de sua inteira disponibilidade aos empregadores e alunos (estes também em certa medida empregadores, se considerarmos a educação privada), os desafios operacionais que as aulas online tem proporcionado em suas atividades laborais (dificuldades de conectividade, aquisição de equipamento técnico necessários para aula), além das respostas que demandam a instituição, os pais e a sociedade têm ocasionado à estes profissionais um intenso enfraquecimento de suas garantias trabalhistas, uma vez que ao assumir responsabilidades que vêm sendo impostas pelo Estado e Capital, o profissional acaba incumbindo-se de atribuiçôes que não deveriam ser suas.

Praun (2020) indica que o ensino a distância tem se apresentado como um falso recurso para a continuidade das atividades no ensino básico e universitário. A autora questiona a efetividade do ensino remoto e chama a atençáo para o acirramento das desigualdades que se expressam a partir desse modelo,

As experiências relatadas por docentes, estudantes e seus familiares indicam que, para além do acesso ao material de estudo, que, em alguns casos, passou a ser 
enviado aos estudantes na forma impressa, entram em cena a reproduçáo de velhas desigualdades, ampliadas no contexto da pandemia e marcadas pelas 'soluçóes' individualizantes propostas pela cartilha neoliberal. Tal dinâmica pode ser observada, entre tantos outros exemplos, pela experiência de Letícia, mãe de nove filhos e moradora de uma das favelas de Belo Horizonte. Analfabeta, sem condiçóes de auxiliar o acesso de um de seus filhos ao material de estudo impresso, desistiu de buscá-lo na escola. Quantas Letícias se sentirão injustamente responsabilizadas pela interrupção dos estudos de seus filhos e filhas? Que perspectivas de acesso à educação podem oferecer os experimentos que vêm sendo praticados sob a lógica do cumprimento, a qualquer custo, dos cronogramas escolares? Que futuro essas práticas reservam para o trabalho docente? (PRAUN,2020, p. 5)

O mundo digital ocupa um lugar extremamente importante quando se analisa o trabalho e suas contradiçóes. Antunes e Filgueiras (2020) destacam que, contrariamente ao que se acredita, as plataformas digitais hoje controlam todo o processo do capital quando determinam os "formatos exatos dos contratos de trabalho, pagam, mobilizam, ameaçam e dispensam. Os/as trabalhadores/ as são induzidos a adotar estes comportamentos [...] se querem permanecer exercendo seu labor" (ANTUNES; FILGUEIRAS, 2020, p. 38).

Com a informalidade, esse cenário tende a se agravar para os trabalhadores, uma vez que o aspecto mais perverso frente à contradição existente na relação capital/trabalho claramente se manifesta. De acordo com Chaves (2020), os trabalhadores informais terminam encontrando um cenário ainda mais precarizado do que o apresentado anteriormente para os professores e profissionais de saúde que, ao contrário destes, passam a ter suas relaçóes de trabalho atravessadas pela imposição latente do desemprego estrutural, determinando sua sujeição à exploração para a sua sobrevivência.

A discussão sobre a exploraçáo e dominação a que vem sendo submetida à classe que vive do trabalho não se esgota no contexto da pandemia, ao contrário, ela se aprofunda. Antunes e Filgueiras (2020) argumentam que o trabalho intermitente e desregulamentado é uma estratégia que atende ao empregador que se desobriga da proteção ao trabalhador.

O discurso proposto na era digital como o alardeado empreendedorismo propóe a autonomia total do trabalhador, sendo este o responsável por gerir seu tempo de trabalho. O mercado vem traçando o perfil ideológico dos trabalhadores de aplicativos e plataformas digitais e, consequentemente, moldando e permitindo intenso controle dessa força de trabalho:

A ideia de liberdade e flexibilidade (trabalhar quando e onde quiser) propagada pelas empresas constitui, na verdade, a transferência deliberada de riscos para aumentar o controle sobre os/as trabalhadores/as, pois essa liberdade significa ausência de salário garantido e incremento de custos fixos que se convertem em responsabilidade dos mesmos (ANTUNES; FILGUEIRAS, 2020, p. 33).

Exemplo dessa força de trabalho, os entregadores, motoristas de aplicativos e motoboys dão o tom da máxima precarização em tempos de pandemia. Com a desproteção do Estado, a dificuldade e os entraves para receber o auxílio emergencial, esses informais, que somam milhares de pessoas no Brasil "foram colocados frente a trágica escolha entre o vírus e a fome" (BRAGA; SANTANA,2020, s.p). Assim: 
Como em outras áreas, os aplicativos aproveitaram a pandemia para aumentar seus lucros, incrementando seu controle sobre os/as trabalhadores/as. Dado o alto nível de desemprego e informalidade, e com vários setores com atividade paralisada, a categoria, como já vinha ocorrendo nos últimos anos, recebeu um afluxo grande de novos membros o que aumentou o ganho dos aplicativos, aumentando a competição entre os entregadores/as e, consequentemente, reduzindo seus rendimentos. Reativamente, os/as trabalhadores/as passaram a trabalhar por mais horas a fim de mitigar a queda da remuneração. Trata-se de um jogo viciado no qual apenas as empresas ganham (BRAGA; SANTANA, 2020, s.p.).

Acidentes, mortes e adoecimento perpassam o cotidiano desses trabalhadores que não possuem qualquer garantia ou vínculo empregatício e são submetidos a um absoluto controle das atividades por parte de diversas plataformas digitais. Diante dos primeiros dados apresentados por pesquisadores de universidades brasileiras sobre os impactos nas condiçóes de trabalho de entregadores das principais plataformas digitais, fica patente a intensificação da exploração do trabalho e da desresponsabilização dessas empresas por qualquer dano à saúde destes.

Os primeiros resultados revelam que durante a pandemia houve reduçáo no valor pago aos entregadores por hora trabalhada, o que representa aumento nos ganhos das empresas. No que refere a medidas de proteção e à saúde, os próprios entregadores se responsabilizam por sua proteção, isso envolve custos que não são assumidos pelas empresas (MACHADO et al., 2020). Diante do quadro fica clara a necessidade desses trabalhadores que se submetem a longas jornadas de trabalho "para sobreviver, atenuar suas vicissitudes e manter seu vínculo de trabalho, são obrigados a trabalhar por longas horas, suprimir descansos, intensificar suas jornadas" (ANTUNES,2020, p. 38), cumprindo estritamente as ordens da empresa e obrigatoriamente tendo que gerenciar a sua sobrevivência.

\section{CONSIDERAÇÕES FINAIS}

O capital vem há muito se reorganizando de forma a intensificar ganhos e reduzir gastos. No período vigente, em que a pandemia e o vírus têm ceifado milhares de vidas, discursos como os do professor e economista Boudreaux (2021) ganharam força. A defesa do autor de que o uso obrigatório de máscaras vem cerceando o direito legal e ético "de continuar cuidando de nossas vidas, de continuar trabalhando, de continuar circulando e até mesmo de continuar mantendo nossos afazeres", o que desconsidera o fato que o uso obrigatório de máscaras não é uma escolha, mas sim uma necessidade.

A fala do economista encontra eco em grande parte da sociedade que refuta fortemente a gravidade da pandemia. O negacionismo no Brasil se tornou a tônica das manifestaçôes do presidente Bolsonaro, que reza pela cartilha dos ultraliberais. A classe trabalhadora tem experimentado o acirramento da precarizaçáo das formas de trabalho somada a novos desafios impostos pela pandemia. Supressão de direitos, alta letalidade em decorrência do vírus, baixa remuneração, adoecimento, dependência do auxílio emergencial, desresponsabilização do governo frente às necessidades sociais tem ratificado o quão grave o despreparo/perversidade da atual gestão do país se manifesta sob a lógica daqueles que se norteiam e atuam pela lógica do capitalismo financeiro.

As medidas de prevenção ao vírus, provenientes dos direcionamentos da Organização Mundial da Saúde (OMS) que vão desde a higienização das mãos, distanciamento social e isolamento já se mostraram impossíveis de serem realizadas por determinados segmentos da sociedade. A desigualdade 
estrutural do país tem paulatinamente demonstrado que a precarização do trabalho tem sido forte aliada ao não cumprimento das medidas de segurança, uma vez que os trabalhadores (especialmente os informais) devido a fragilização dos vínculos empregatícios e dificuldades financeiras tem cotidianamente se exposto ao risco de contaminação em busca de subsistência.

\section{REFERÊNCIAS}

ABREU, Igor Souza de; ABREU, Ivan Souza de; SANTOS, Marlene Souza dos. O poder do discurso hegemônico:a influência da narrativa bolsonarista no combate à pandemia da covid-19 no brasil. Anais do 90 Congresso Internacional Interdisciplinar em Sociais e Humanidades, Campos dos Goytacazes (Rj) Uenf, 2020. Disponível em:<https//www.even3.com.br/anais/coninter2020/286986-O-PODERDO-DISCURSO-HEGEMONICO--A-INFLUENCIA-DA-NARRATIVA-BOLSONARISTA-NOCOMBATE-A-PANDEMIA-DA-COVID-19-NO-BRASI>. Acesso em: 29 mar. 2021.

ANTUNES, Ricardo. O Privilégio da Servidáo: o novo proletariado de serviços na era digital. São Paulo: Boitempo, 2018.

. Desenhando a nova morfologia do trabalho no Brasil. Estudos Avançados, [s.l.], vol. 28, n. 81, p. 39-53, 2014.

.; DRUCK, Graça. A terceirização sem limites: a precarização do trabalho como regra. O Social em Questáo, [s.l.], vol. 18, n. 33, p. 19-40, 2015.

. O vilipêndio da Covid-19 e o imperativo de reinventar o mundo. O Social em Questáo, [s.l.], vol. 1, n. 49, 2021

A classe-que-vive-do-trabalho: a forma de ser do trabalhador hoje. In: Os sentidos do trabalho: ensaio sobre afirmação e negação do trabalho. São Paulo: Boitempo, 1999.

BOUDREAUX, Donald. Poderiam ao menos ter a decência de parar com as justificativas bizarras para o lockdown. Mises Brasil. 23 mar 2021. Disponível em https://www.mises.org.br/article/3335/poderiamao-menos-ter-a-decencia-de-parar-com-as-justificativas-bizarras-para-o-lockdown. Acesso em: 15 jun. 2021.

BRAGA, Ruy; SANTANA, Marco Aurélio. \#BrequeDosApps: enfrentando o uberismo. 2020.Disponível em: https://blogdaboitempo.com.br/2020/07/25/brequedosapps-enfrentando-o-uberismo/. Acesso em: 27 mar. 2021.

CHAVES, Andréa Bittencourt Pires. Da Planta taylorista/fordista ao capitalismo de plataforma: as engrenagens da exploração do trabalho. Research, Society and Development, [s.l.], vol. 9, n.6, p. e01963473- e01963473, 2020.

CONSELHO FEDERAL DE ENFERMAGEM (COFEN). Brasil representa um terço das mortes de profissionais de Enfermagem por covid-19. 08 jan 2021.Disponível em :http://www.cofen.gov.br/brasilresponde-por-um-terco-das-mortes-de-profissionais-de-enfermagem-por-covid-19_84357.html. Acesso em: 20 mar 2021.

.A difícil realidade dos enfermeiros diante à pandemia. 23 mar 2021. Disponível em : http://www. cofen.gov.br/a-dificil-realidade-dos-enfermeiros-diante-a-pandemia_85957.html. Acesso em : 24 mar 2021. 
.Covid-19: Estudo avalia condições de trabalho na Saúde. 22 mar 2021. Disponível em :http://www. cofen.gov.br/covid-19-estudo-avalia-condicoes-de-trabalho-na-saude_85928.htm Acesso em 24 mar 2021.

IAMAMOTO, Marilda V. Serviço Social em tempo de capital fetiche: capital financeiro, trabalho e questão social. São Paulo. Cortez, 2007.

INSTITUTO DE PESQUISA ECONÔMICA APLICADA (IPEA). CORSEUIL, Carlos Henrique et al.Comportamento do mercado de trabalho brasileiro em duas recessóes: análise do período 2015-2017 e da pandemia de Covid-19. Nota técnica 92. Ipea. 2021.

KREIN, José Dari. O desmonte dos direitos, as novas configuraçōes do trabalho e o esvaziamento da ação coletiva: consequências da reforma trabalhista. Tempo social, [s.l.], vol. 30, n. 1, p. 77-104, 2018.

LESSA, Sérgio. Mundo dos homens: trabalho e ser social. São Paulo: Instituto Lukács, 2012.

Relatório Parcial de Pesquisa. ABÍLIO, Ludmila. C.; ALMEIDA, Paula. F.; AMORIM, Henrique; CARDOSO, Ana. C. M.; FONSECA, Vanessa. P.; KALIL, Renan. B.; MACHADO, Sidnei. Condiçóes de trabalho em empresas de plataforma digital: os entregadores por aplicativo durante a Covid-19. São Paulo: REMIR, 2020. 11 p,

MARX, Karl. Contribuiçáo à crítica da economia política. 2 ed. São Paulo: Expressão Popular. 2008

O capital: Crítica da economia política. Livro I: O processo de produção do capital. Trad. de Rubens Enderle. São Paulo: Boitempo, 2013.

MÁXIMO, Wellton. Em dois meses, 107 milhões de pessoas pediram auxílio emergencial. Agência Brasil, Brasília, 3 jun. 2020. Disponível em: https://agenciabrasil.ebc.com.br/economia/noticia/2020-06/emdoismeses-107-milhoes-de-brasileiros-pediram-auxilio-emergencial. Acesso em: 23 jun. 2020.

MOTA, Ana Elizabete. Sobre as expropriaçóes contemporâneas: hipótese é reflexôes.p. 1a 12.Disponível em: http://www.niepmarx.blog.br/MM2017/anais2017/MC44/mc444.pdf. Acesso em:02 fev. 2021.

PRAUN, Luci. A Espiral da Destruição: legado neoliberal, pandemia e precarização do trabalho. Trabalho, Educaçáo e Saúde, [s.l.], vol. 18, n. 3, 2020.

TUCKER, Jeffrey. Lockdown: a nova ideologia totalitária. Mises Brasil. 26, fev, 2021. Disponível em : https://mises.org.br/article/3298/lockdown-a-nova-ideologia-totalitaria

SANTOS, Boaventura Sousa. Vírus: tudo que é sólido se desfaz no ar. Público. 18, mar 2019. Disponível em http://www.boaventuradesousasantos.pt/media/V\%C3\%ADrus\%20-\%20Tudo\%20o\%20que\%20 \%C3\%A9\%20s\%C3\%B3lido\%20se\%20desfaz\%20no\%20ar_18Mar20.pdf 